\title{
Diagnostic Assessment and Mathematical Difficulties: An Experimental Study of Dyscalculia
}

\author{
Ahmad Rababah', Yazan Alghazo ${ }^{2 *}$ \\ ${ }^{1}$ Dammam University, Al-Dammam, KSA \\ ${ }^{2}$ Prince Mohammad Bin Fahd University, Al Khobar, KSA \\ Email: *Yghazo@pmu.edu.sa
}

Received 18 May 2016; accepted 6 June 2016; published 9 June 2016

Copyright (C) 2016 by authors and Scientific Research Publishing Inc.

This work is licensed under the Creative Commons Attribution International License (CC BY). http://creativecommons.org/licenses/by/4.0/

(c) (i) Open Access

\begin{abstract}
Diagnostic assessment strategies are used to enhance student achievement within several different subject areas. In this study, a diagnostic assessment program was designed and implemented with a group of students diagnosed with Dyscalculia. Students in both the control group and the treatment groups were given a pre-test and a post-test, and results from those tests were used to assess the effectiveness of the program. The findings revealed statistically significant differences between the control group and the treatment groups on the post-test, which indicated that the diagnostic assessment strategy was effective in improving dyscalculic students' mathematical abilities. The design and implementation of the program, as well as the implications of the findings, are discussed in this article.
\end{abstract}

\section{Keywords}

Mathematical Difficulties, Dyscalculia, Diagnostic Assessment Strategy

\section{Introduction}

Diagnostic assessment strategies have widely been used to enhance student achievement across different subject areas [1]. More specifically, such programs were designed and implemented to assess and support the learning of students with learning difficulties in reading (Dyslexia), writing (Dysgraphia), and Mathematics (Dyscalculia) [1]. Research has shown that students who undergo such programs show significant improvement in their abilities once the program's implementation is completed. Diagnostic assessment strategies allow teachers to provide

*Corresponding author. 
a dynamic learning and teaching environment that enables them to accommodate different, individual student needs and abilities. Furthermore, another advantage of implementing diagnostic assessment program is that it helps teachers utilize different educational tools in order to achieve the educational goals.

The purpose of this study is to investigate the effect of implementing a diagnostic assessment strategy on students who are diagnosed with dyscalculia. The researchers aim at providing further evidence for the usefulness of such programs in the treatment of learning difficulties in general, and mathematics difficulties specifically.

The study attempted to answer the following research questions:

1) Is there a statistically significant difference between pre- and post-test scores for the treatment group?

2) Is there a statistically significant difference between pre- and post-test scores for the control group?

\section{Literature Review}

A range of terms for referring to developmental math disability has emerged, along with different criteria used to measure it. According to [2], the term "mathematical disabilities" is used to include all children who fall below the $30^{\text {th }}$ percentile [3] or $35^{\text {th }}$ percentile [4] on the Woodcock-Johnson Mathematics reasoning test [5]. References [6]-[8] refer to "mathematics difficulties", and include all children below the $35^{\text {th }}$ percentile of the Woodcock-Johnson Broad Mathematics Composite Score. The $35^{\text {th }}$ percentile criterion means that the best children will be about 0.39 SD units below the mean, and that $90 \%$ of the sample will be better than 2 SDs below the mean. Reference [9] uses the term "arithmetic learning disabilities" and include children below the $25^{\text {th }}$ percentile on the Iowa Test of Basic Skills. Most children so classified would fall between 0.67 and 1.18 SDs below the expected mean, and could thus be regarded as in the low average or even the average range. These authors' terminology, as well as criteria, make it clear that they are considering a range of causes for low mathematics achievement, not just the clinical condition of dyscalculia.

Researchers agree that dyscalculia appears as a problem in learning arithmetic facts and calculation procedures. The question which remains unanswered relates to the underlying deficits which cause these problems. Various candidates have been put forward, including dyslexic difficulties, memory difficulties, spatial difficulties and attentional difficulties. However, many of the studies which have been designed to relate these "underlying" abilities to dyscalculia have confounded them with numerical processing abilities [10].

Researchers have continuously studied the possibilities and different instructional strategies that can be used in order to assist the learning process of students with mathematical learning difficulties. For example, [11] conducted a study utilizing specific instruction directed towards specific mathematical skills, such as counting and found that dyscalculic students who received specific instruction outperformed their peers who did not receive specialized instruction. Similarly, [12] implemented an intervention that focuses on basic numeracy skills as well as conceptual knowledge and concluded that children with mathematics difficulties benefit significantly from the intervention.

Other researchers utilized computer assisted training to dyscalculic students as the intervention method [13] [14], and found that students benefited from the intervention. Moreover, [1] conducted a study in which they implemented a training program for students with mathematics difficulties and students diagnosed with dyscalculia; their findings suggest that individualized instruction as well specific instruction on mathematical tasks benefits both groups of students. Moreover, researchers have suggested that specific mathematics intervention at early ages can be used to prevent future mathematics difficulties [15].

In this article, the researchers report the findings of implementing a diagnostic assessment teaching strategy in order to improve the mathematical and numeracy skills of students diagnosed with dyscalculia.

\section{Methodology}

\subsection{Context}

The study was implemented in the context of the public school system is the Kingdom of Saudi Arabia. Three elementary schools were randomly selected from a pool of 20 elementary schools within the Eastern Province, which include a resource room for children with special needs. Public schools in KSA offer accommodations for students with diagnosed special needs through resource rooms within the same school building. Students are pulled out of regular classrooms and placed in resource rooms for individual instruction in the content area in which they have learning difficulties. 


\subsection{Research Design}

The research design for this study is an experimental design in which two groups were randomly selected. The first group (Group A) was assigned to the treatment (Diagnostic Assessment Program), and the second group (Group B) was assigned as the control group. The treatment group included 26 students from two different schools, who had been diagnosed by the ministry of Education in Saudi Arabia with severe learning difficulties in mathematics (Dyscalculia), and each group was utilized as a separate treatment group to measure if any individual differences might affect the outcome of the treatment and the control group included 15 students from one school who were also diagnosed with dyscalculia.

Resource room teachers in the schools that were assigned as the treatment groups underwent a training program for two weeks on the implementation of the Diagnostic Assessment strategy. Teachers, who teach the control group, did not receive any specific training. All groups were given a pre-test and a post-test (Diagnostic Assessment of Basic Mathematics Skills). Table 1 shows the distribution and percentages of students within each of the groups.

\subsection{Instruments}

\subsubsection{Diagnostic Teaching Program}

The program was designed on the basis of the common core standards for mathematics, which are applied in a majority of KSA schools. Those Standards or dimensions include: 1) Number recognition (D1) and Number Sense (D2), Ordering Numbers (D3), and Rounding (D4). 2) Basic Arithmetic which includes addition (D5), subtraction (D6), multiplication (D7) and division (D8).

Students are given a lesson for each learning objective, as well as a diagnostic assessment at the end of each lesson in order to measure their mastery of the learning objective. If students demonstrated $80 \%$ mastery of the lesson's objective, the teacher would then move on to the next lesson. However, if students were not able to achieve the desired level of mastery for that lesson, the teacher would then design and deliver a second lesson on the same learning objective using different teaching strategies as well as different learning materials for the lesson based on the feedback from the diagnostic assessment results. Table 2 shows a three lesson plan for three learning objectives within the program as an example.

\subsubsection{Diagnostic Assessment of Basic Mathematical Skills}

The assessment utilized in this study is a self-designed assessment that measures basic mathematical skills for the elementary school levels. The forty test items were designed based on a thorough analysis of the curriculum as well as comparison with several other tests and assessments utilized by schools within Saudi Arabia, as well as standardized international assessments of basic mathematical skills. Twenty items were developed for each of the learning objectives that cover: 1) Number recognition and Number Sense, Ordering Numbers, and Rounding. 2) Basic Arithmetic which includes addition, subtraction, multiplication and division. The test is designed to identify the strengths and weaknesses of students with regards to specific learning objectives or mathematical skills. The test also helps identify whether a student has achieved the minimum mastery level in order to build or construct further mathematical concepts that will be taught in future units of instruction. Items are graded on a True/False basis, where correct answers received one point and incorrect answers received zero points.

\subsubsection{Validity and Reliability}

To validate the instrument, the Diagnostic Assessment of Basic Mathematics Skills (DABMS) was evaluated by a panel of five university professors at Dammam University and two school teachers in order to check each item on the test and verify that they measure the targeted mathematical skills and are directly related to the learning objectives specified in the program description.

Table 1. Student distributions in treatment and control groups.

\begin{tabular}{ccc}
\hline Group & Size (N) & Percentage \\
\hline Treatment Group one & 14 & $34 \%$ \\
Treatment Group two & 12 & $29 \%$ \\
Control Group & 15 & $37 \%$ \\
\hline
\end{tabular}


Table 2. A two lesson example from the diagnostic assessment program.

\begin{tabular}{|c|c|c|c|c|}
\hline Standard & Learning Objective & Sub-Objective & Teaching Methods & Assessment Method \\
\hline $\begin{array}{l}\text { Number } \\
\text { Recognition }\end{array}$ & $\begin{array}{l}\text { Recognize Numbers and be } \\
\text { able to read them }\end{array}$ & $\begin{array}{l}\text { - } \\
\text { read one digit numbers. } \\
\text { - } \quad \text { Students will be able to } \\
\text { read Two Digit numbers. } \\
\text { - } \quad \text { Students will be able to } \\
\text { read three digit numbers. }\end{array}$ & $\begin{array}{l}\text { - } \quad \text { Use of manipulatives } \\
\text { (Coins, objects). } \\
\text { - } \quad \text { Smart-board interactive } \\
\text { activities. } \\
\text { - } \quad \text { Flash Cards. }\end{array}$ & $\begin{array}{l}\text { Mastery-based Assessment at } \\
\text { the end of each lesson to } \\
\text { measure the mastery level of } \\
\text { the learning objective using } \\
\text { written and verbal tests. }\end{array}$ \\
\hline $\begin{array}{l}\text { Ordering } \\
\text { numbers }\end{array}$ & $\begin{array}{l}\text { Students will be able to order a } \\
\text { set of number from highest to } \\
\text { lowest and from lowest to } \\
\text { highest. }\end{array}$ & $\begin{array}{l}\text { - Students will be able to } \\
\text { order numbers from highest } \\
\text { to lowest. } \\
\text { - Students will be able to } \\
\text { order numbers from lowest to } \\
\text { highest. }\end{array}$ & $\begin{array}{l}\text { - Use online activities and } \\
\text { games designed for this lesson. } \\
\text { (Forest ordering game) } \\
\text { - } \quad \text { Flash cards. }\end{array}$ & $\begin{array}{l}\text { Mastery-based Assessment at } \\
\text { the end of each lesson to } \\
\text { measure the mastery level of } \\
\text { the learning objective using } \\
\text { written and verbal tests. }\end{array}$ \\
\hline Rounding & $\begin{array}{l}\text { - Students will be able to } \\
\text { round numbers. }\end{array}$ & $\begin{array}{l}\text { - Students will be able to } \\
\text { round numbers to the nearest } \\
\text { ten. } \\
\text { - Students will be able to } \\
\text { round numbers to the nearest } \\
100 .\end{array}$ & $\begin{array}{l}\text { - In-Class group } \\
\text { activities using paper } \\
\text { worksheets. } \\
\text { - Interactive games played } \\
\text { as a group on the smart-board. }\end{array}$ & $\begin{array}{l}\text { Mastery-based Assessment at } \\
\text { the end of each lesson to } \\
\text { measure the mastery level of } \\
\text { the learning objective using } \\
\text { written and verbal tests. }\end{array}$ \\
\hline
\end{tabular}

To test the reliability of the instrument, the researchers implemented the test on a group of students $(\mathrm{N}=31)$ twice with a period of three weeks in between the test and re-test. A reliability coefficient of 0.78 was found.

\section{Data Analysis and Results}

Data analysis showed that there were no statistically significant differences in students' scores on the pretest between the control group and either of the treatment groups. Moreover, there were no statistically significant differences between the control groups on the pretest scores. This suggests that all students in all three groups had similar levels of mathematical understanding and abilities at the beginning of this experiment.

Data analysis after the post-test revealed a statistically significant difference in scores between the control group and both treatment group A and treatment group B. This suggests that students who were in the classes where the diagnostic assessment strategy was implemented improved more than those who received regular instruction with regard to their mathematical abilities.

Table 3 shows the mean scores and standard deviations that were calculated for both treatment groups, as well as the control group for the pre-test and the post-test. The mean score for Treatment group A was 34.856, and for Treatment group B 35.578, while the mean score for the control group was 25.139. To measure the effectiveness of the treatment program an analysis of covariance test was conducted on the total scores as shown in Table 4.

Table 4 shows there exists statistically significant differences between the treatment groups and the control groups. The effect size was 0.812 , which means that the treatment program was very effective in improving students' mathematical abilities.

Table 5 shows the results of a T-test to compare between the two treatment groups with regard to the post-test scores. The results showed no statistically significant differences between treatment group A and treatment group B on the Post-test scores. This suggests that both groups benefited from the treatment equally, and that all students in both groups showed similar improvement in mathematical abilities.

To further test for differences between the control group and the treatment groups on the specific eight dimensions within the DABMS test, means and standard deviations were calculated for the pre and post-tests (see Table 6) and a Multivariate Analysis of Covariance (MANCOVA) was conducted (See Table 7). The results showed that there was no statistically significant difference between the control group and the treatment groups on dimension on (D1, Number Recognition), while there were statistically significant differences between the control group and the treatment group on all other seven dimensions D2, D3, ..., D8. Which further emphasizes the effectiveness of the diagnostic assessment program.

\section{Conclusions}

The main goal of this study was to investigate the effectiveness of implementing a diagnostic assessment strategy 
Table 3. Means and standard deviations of pre and post tests.

\begin{tabular}{cccccccc}
\hline \multirow{2}{*}{$\begin{array}{c}\text { Test } \\
\text { Group }\end{array}$} & \multicolumn{2}{c}{ Pre-test } & \multicolumn{2}{c}{ Post-test } & \multicolumn{3}{c}{ Adjusted Means Post-test } \\
\cline { 2 - 8 } & Mean & SD & Mean & SD & Mean & SD & N \\
\hline Treatment A & 21.4286 & 2.59331 & 34.8571 & 2.38125 & $34.856^{\text {a }}$ & 0.655 & 14 \\
Treatment B & 21.5833 & 2.23437 & 35.5833 & 3.26018 & $35.578^{\mathrm{a}}$ & 0.708 & 12 \\
Control & 21.2000 & 2.54109 & 25.1333 & 1.50555 & $25.139^{\mathrm{a}}$ & 0.633 & 15 \\
Total & 21.3902 & 2.41742 & 31.5122 & 5.45033 & $31.858^{\mathrm{a}}$ & 0.384 & 41 \\
\hline
\end{tabular}

Table 4. Analysis of covariance.

\begin{tabular}{ccccccc}
\hline Covariance sources & Square total & $d f$ & Mean square & F & P & sig \\
\hline group & 960.570 & 2 & 480.285 & 79.979 & $\underline{\mathbf{0 . 0 0 0}}$ & 0.812 \\
pretest & 0.175 & 1 & 0.175 & 0.029 & 0.866 & 0.001 \\
error & 222.190 & 37 & 6.005 & & & \\
total & 1188.244 & 40 & & & \\
\hline
\end{tabular}

\begin{tabular}{|c|c|c|c|c|c|c|c|}
\hline Post-test & Group & $\mathrm{N}$ & Mean & SD & T value & $d f$ & sig \\
\hline \multirow{2}{*}{ post. D1 } & Treatment A & 14 & 6.0714 & 1.14114 & \multirow[t]{2}{*}{$-0.621-$} & \multirow[t]{2}{*}{24} & \multirow[t]{2}{*}{0.541} \\
\hline & Treatment B & 12 & 6.3333 & 0.98473 & & & \\
\hline \multirow{2}{*}{ post. D2 } & Treatment A & 14 & 6.4286 & 0.85163 & \multirow[t]{2}{*}{$-0.661-$} & \multirow[t]{2}{*}{24} & \multirow[t]{2}{*}{0.515} \\
\hline & Treatment B & 12 & 6.6667 & 0.98473 & & & \\
\hline \multirow{2}{*}{ post. D3 } & Treatment A & 14 & 6.4286 & 0.85163 & \multirow[t]{2}{*}{1.135} & \multirow[t]{2}{*}{24} & \multirow[t]{2}{*}{0.268} \\
\hline & Treatment B & 12 & 6.0833 & 0.66856 & & & \\
\hline \multirow{2}{*}{ post. D4 } & Treatment A & 14 & 5.0000 & 0.67937 & \multirow[t]{2}{*}{0.825} & \multirow[t]{2}{*}{24} & \multirow[t]{2}{*}{0.418} \\
\hline & Treatment B & 12 & 4.7500 & 0.86603 & & & \\
\hline \multirow{2}{*}{ post. D5 } & Treatment A & 14 & 4.0714 & 0.73005 & \multirow[t]{2}{*}{$-1.877-$} & \multirow[t]{2}{*}{24} & \multirow[t]{2}{*}{0.073} \\
\hline & Treatment B & 12 & 4.6667 & 0.88763 & & & \\
\hline \multirow{2}{*}{ post. D6 } & Treatment A & 14 & 3.2143 & 0.57893 & \multirow[t]{2}{*}{$-1.163-$} & \multirow[t]{2}{*}{24} & \multirow[t]{2}{*}{0.256} \\
\hline & Treatment B & 12 & 3.5000 & 0.67420 & & & \\
\hline \multirow{2}{*}{ post. D7 } & Treatment A & 14 & 2.9286 & 0.73005 & \multirow[t]{2}{*}{0.665} & \multirow[t]{2}{*}{24} & \multirow[t]{2}{*}{0.512} \\
\hline & Treatment B & 12 & 2.7500 & 0.62158 & & & \\
\hline \multirow{2}{*}{ post. D8 } & Treatment A & 14 & 0.7143 & 0.72627 & \multirow[t]{2}{*}{$-0.389-$} & \multirow[t]{2}{*}{24} & \multirow[t]{2}{*}{0.701} \\
\hline & Treatment B & 12 & 0.8333 & 0.83485 & & & \\
\hline \multirow{2}{*}{ post. Total } & Treatment A & 14 & 34.8571 & 2.38125 & \multirow[t]{2}{*}{$-0.655-$} & \multirow[t]{2}{*}{24} & \multirow[t]{2}{*}{0.519} \\
\hline & Treatment B & 12 & 35.5833 & 3.26018 & & & \\
\hline
\end{tabular}

of instruction in helping students with dyscalculia improve their mathematical abilities. Two treatment groups and one control group were randomly selected, and given instruction in mathematics for a period of two months.

The findings revealed that students who were in the treatment groups and received diagnostic assessment based instruction showed more improvement than students in the control group, which suggested that the diagnostic assessment strategy was effective in significantly improving dyscalculic students’ mathematical abilities. 
Table 6. Means and standard deviations of pre and post test.

\begin{tabular}{|c|c|c|c|c|c|c|c|c|}
\hline \multirow[b]{2}{*}{ Dimension } & \multirow{2}{*}{$\begin{array}{l}\text { Test } \\
\text { Group }\end{array}$} & \multicolumn{2}{|c|}{ Pre-Test } & \multicolumn{2}{|c|}{ Post-Test } & \multicolumn{2}{|c|}{ Marginal Post-Test } & \multirow[b]{2}{*}{$\mathrm{N}$} \\
\hline & & Mean & SD & Mean & SD & Mean & SD & \\
\hline \multirow{4}{*}{ D1 } & Treatment A & 5.2857 & 0.72627 & 6.0714 & 1.14114 & $6.066^{\mathrm{a}}$ & 0.285 & 14 \\
\hline & Treatment B & 5.2500 & 0.96531 & 6.3333 & 0.98473 & $6.344^{\mathrm{a}}$ & 0.327 & 12 \\
\hline & Control & 5.2000 & 0.77460 & 5.6667 & 0.81650 & $5.664^{\mathrm{a}}$ & 0.279 & 15 \\
\hline & Total & 5.2439 & 0.79939 & 6.0000 & 1.00000 & $6.024^{\mathrm{a}}$ & 0.165 & 41 \\
\hline \multirow{4}{*}{ D2 } & Treatment A & 4.5000 & 0.75955 & 6.4286 & 0.85163 & $6.392^{\mathrm{a}}$ & 0.229 & 14 \\
\hline & Treatment B & 4.1667 & 0.57735 & 6.6667 & 0.98473 & $6.724^{\mathrm{a}}$ & 0.263 & 12 \\
\hline & Control & 4.5333 & 0.74322 & 4.8667 & 0.74322 & $4.855^{\mathrm{a}}$ & 0.224 & 15 \\
\hline & Total & 4.4146 & 0.70624 & 5.9268 & 1.17026 & $5.990^{\mathrm{a}}$ & 0.133 & 41 \\
\hline \multirow{4}{*}{ D3 } & Treatment A & 4.2143 & 0.89258 & 6.4286 & 0.85163 & $6.452^{\mathrm{a}}$ & 0.205 & 14 \\
\hline & Treatment B & 4.4167 & 0.66856 & 6.0833 & 0.66856 & $6.105^{\mathrm{a}}$ & 0.236 & 12 \\
\hline & Control & 4.2000 & 0.67612 & 4.6000 & 0.82808 & $4.560^{\mathrm{a}}$ & 0.201 & 15 \\
\hline & Total & 4.2683 & 0.74244 & 5.6585 & 1.13159 & $5.706^{\mathrm{a}}$ & 0.119 & 41 \\
\hline \multirow{4}{*}{ D4 } & Treatment A & 2.5714 & 1.01635 & 5.0000 & 0.67937 & $4.993^{\mathrm{a}}$ & 0.222 & 14 \\
\hline & Treatment B & 2.9167 & 0.66856 & 4.7500 & 0.86603 & $4.798^{\mathrm{a}}$ & 0.255 & 12 \\
\hline & Control & 2.5333 & 1.06010 & 3.8000 & 0.94112 & $3.768^{\mathrm{a}}$ & 0.217 & 15 \\
\hline & Total & 2.6585 & 0.93834 & 4.4878 & 0.97780 & $4.520^{\mathrm{a}}$ & 0.129 & 41 \\
\hline \multirow{4}{*}{ D5 } & Treatment A & 2.7143 & 0.72627 & 4.0714 & 0.73005 & $4.095^{\mathrm{a}}$ & 0.166 & 14 \\
\hline & Treatment B & 2.5833 & 1.16450 & 4.6667 & 0.88763 & $4.509^{\mathrm{a}}$ & 0.190 & 12 \\
\hline & Control & 2.7333 & 0.70373 & 2.6667 & 0.61721 & $2.770^{\mathrm{a}}$ & 0.162 & 15 \\
\hline & Total & 2.6829 & 0.84968 & 3.7317 & 1.11858 & $3.792^{\mathrm{a}}$ & 0.096 & 41 \\
\hline \multirow{4}{*}{ D6 } & Treatment A & 1.2143 & 0.80178 & 3.2143 & 0.57893 & $3.230^{\mathrm{a}}$ & 0.157 & 14 \\
\hline & Treatment B & 1.3333 & 0.77850 & 3.5000 & 0.67420 & $3.454^{\mathrm{a}}$ & 0.180 & 12 \\
\hline & Control & 1.2000 & 0.77460 & 1.8000 & 0.41404 & $1.822^{\mathrm{a}}$ & 0.153 & 15 \\
\hline & Total & 1.2439 & 0.76748 & 2.7805 & 0.93574 & $2.835^{\mathrm{a}}$ & 0.091 & 41 \\
\hline \multirow{4}{*}{ D7 } & Treatment A & 0.5714 & 0.51355 & 2.9286 & 0.73005 & $2.927^{\mathrm{a}}$ & 0.196 & 14 \\
\hline & Treatment B & 0.5833 & 0.51493 & 2.7500 & 0.62158 & $2.726^{\mathrm{a}}$ & 0.225 & 12 \\
\hline & Control & 0.4667 & 0.51640 & 1.2000 & 0.77460 & $1.220^{\mathrm{a}}$ & 0.191 & 15 \\
\hline & Total & 0.5366 & 0.50485 & 2.2439 & 1.06725 & $2.291^{\mathrm{a}}$ & 0.113 & 41 \\
\hline \multirow{4}{*}{ D8 } & Treatment A & 0.3571 & 0.49725 & 0.7143 & 0.72627 & $0.752^{\mathrm{a}}$ & 0.197 & 14 \\
\hline & Treatment B & 0.3333 & 0.49237 & 0.8333 & 0.83485 & $0.792^{\mathrm{a}}$ & 0.226 & 12 \\
\hline & Control & 0.3333 & 0.48795 & 0.5333 & 0.51640 & $0.531^{\mathrm{a}}$ & 0.192 & 15 \\
\hline & Total & 0.3415 & 0.48009 & 0.6829 & 0.68699 & $0.692^{\mathrm{a}}$ & 0.114 & 41 \\
\hline
\end{tabular}

This finding further supports the findings of previous studies (i.e. Fuchs et al., 2010; Kauffman, Handl, and Thony, 2003) that found that certain types of specialized instruction can improve the mathematical abilities and performance of Dyscalculic students 
Table 7. Multivariate analysis of covariance.

\begin{tabular}{cccccc}
\hline Source & Independent variables & $d f$ & $\mathrm{~F}$ & $\mathrm{P}$ & Sig \\
\hline & post.D1 & 2 & 1.235 & 0.305 & 0.076 \\
& post.D2 & 2 & 17.548 & $\underline{\mathbf{0 . 0 0 0}}$ & 0.539 \\
post.D3 & 2 & 24.403 & $\underline{\mathbf{0 . 0 0 0}}$ & 0.619 \\
Group & post.D4 & 2 & 8.867 & $\underline{\mathbf{0 . 0 0 1}}$ & 0.372 \\
Sig =0.000 & post.D5 & 2 & 27.404 & $\underline{\mathbf{0 . 0 0 0}}$ & 0.646 \\
& post.D6 & 2 & 29.993 & $\underline{\mathbf{0 . 0 0 0}}$ & 0.667 \\
& post.D7 & 2 & 22.707 & $\underline{\mathbf{0 . 0 0 0}}$ & 0.602 \\
\hline
\end{tabular}

The findings of this study suggest a need for further development and implementation of specific diagnostic assessment based programs in order to assist students with dyscalculia in becoming more able to overcome their mathematical difficulties, especially in early years.

\section{References}

[1] Re, A.M., Pedron, M., Tressoldi, P.E. and Lucangeli, D. (2014) Response to Specific Training for Students with Different Levels of Mathematical Difficulties. Exceptional Children, 80, 337-352. http://dx.doi.org/10.1177/0014402914522424

[2] Price, G.R. and Ansari, D. (2013) Dyscalculia: Characteristics, Causes, and Treatments. Numeracy, 6, 2. http://dx.doi.org/10.5038/1936-4660.6.1.2

[3] Geary, D.C., Hoard, M.K. and Hamson, C.O. (1999) Numerical and Arithmetical Cognition: Patterns of Functions and Deficits in Children at Risk for a Mathematical Disability. Journal of Experimental Child Psychology, 74, $213-239$. http://dx.doi.org/10.1006/jecp.1999.2515

[4] Geary, D.C., Hamson, C.O. and Hoard, M.K. (2000) Numerical and Arithmetical Cognition: A Longitudinal Study of Process and Concept Deficits in Children with Learning Disability. Journal of Experimental Child Psychology, 77, 236-263. http://dx.doi.org/10.1006/jecp.2000.2561

[5] Woodcock, R.W. and Johnson, M.B. (1990) Woodcock-Johnson Psycho-Educational Battery-Revised. DLM Teaching Resources, Allen.

[6] Hanich, L.B., Jordan, N.C., Kaplan, D. and Dick, J. (2001) Performance across Different Areas of Mathematical Cognition in Children with Learning Difficulties. Journal of Educational Psychology, 93, 615. http://dx.doi.org/10.1037/0022-0663.93.3.615

[7] Jordan, N.C., Hanich, L.B. and Kaplan, D. (2003) A Longitudinal Study of Mathematical Competencies in Children with Specific Mathematics Difficulties versus Children with Comorbid Mathematics and Reading Difficulties. Child Development, 74, 834-850. http://dx.doi.org/10.1111/1467-8624.00571

[8] Jordon, N.C., Kaplan, D. and Hanich, L.B. (2002) Achievement Growth in Children with Learning Difficulties in Mathematics: Findings of a Two-Year Longitudinal Study. Journal of Educational Psychology, 94, 586. http://dx.doi.org/10.1037/0022-0663.94.3.586

[9] Koontz, K.L. (1996) Identifying Simple Numerical Stimuli: Processing Inefficiencies Exhibited by Arithmetic Learning Disabled Children. Mathematical Cognition, 2, 1-24. http://dx.doi.org/10.1080/135467996387525

[10] Landerl, K., Bevan, A. and Butterworth, B. (2004) Developmental Dyscalculia and Basic Numerical Capacities: A Study of 8-9-Year-Old Students. Cognition, 93, 99-125. http://dx.doi.org/10.1016/j.cognition.2003.11.004

[11] Fuchs, L.S., Powell, S.R., Seethaler, P.M., Cirino, P.T., Fletcher, J.M., Fuchs, D. and Hamlett, C.L. (2010) The Effects of Strategic Counting Instruction, with and without Deliberate Practice, on Number Combination Skill among Students with Mathematics Difficulties. Learning and Individual Differences, 20, 89-100. http://dx.doi.org/10.1016/j.lindif.2009.09.003

[12] Kaufmann, L., Handl, P. and Thöny, B. (2003) Evaluation of a Numeracy Intervention Program Focusing on Basic Numerical Knowledge and Conceptual Knowledge: A Pilot Study. Journal of Learning Disabilities, 36, 564-573. http://dx.doi.org/10.1177/00222194030360060701

[13] Kucian, K., Grond, U., Rotzer, S., Henzi, B., Schönmann, C., Plangger, F. and von Aster, M. (2011) Mental Number 
Line Training in Children with Developmental Dyscalculia. Neuroimage, 57, 782-795. http://dx.doi.org/10.1016/j.neuroimage.2011.01.070

[14] Räsänen, P., Salminen, J., Wilson, A.J., Aunio, P. and Dehaene, S. (2009) Computer-Assisted Intervention for Children with Low Numeracy Skills. Cognitive Development, 24, 450-472. http://dx.doi.org/10.1016/j.cogdev.2009.09.003

[15] Dowker, A. (2005) Early Identification and Intervention for Students with Mathematics Difficulties. Journal of Learning Disabilities, 38, 324. http://dx.doi.org/10.1177/00222194050380040801 